International

Medical Society

http://imedicalsociety.org

\title{
Knowledge Workers on Occupational Hazards in the Industry of Ceramics \\ OूतCINAI
}

Luiz Carlos Dantas de Sena Junior1, Raissa Estefany Alves da Silva1, Larissa Mendonça Torre ${ }^{2}$, Yanna Gomes de Sousa ${ }^{2}$, Soraya Maria de Medeiros ${ }^{3}$, Jovanka Bittencourt Leite de Carvalho ${ }^{4}$

\section{Abstract}

Introduction: The changes that occurred in recent decades in the labor market have affected the health of individuals and the collective of workers. Work intensification is a characteristic of the current phase of capitalism. The uncertainty generated by fear of unemployment makes people undergo precarious schemes and employment contracts, receiving low wages and risking their lives and health in unhealthy environments, of high risk.

Objectives: To identify the awareness of occupational risks on workers in a ceramics factory to which they are exposed.

Methods: Exploratory, descriptive and qualitative study, conducted with 12 workers from October to November 2015. The focus group methodology was used as a process to data collection to obtain qualitative information in depth. Results: we identified sufficient awareness of workers on the types of risks in the performance of their activities and concern about the possible effects that these activities can cause to health.

Conclusions: It is evident from this study to provide support for planning and adjustments in working conditions of ceramic factory workers by the employer, promote educational activities to clarify and sensitize the workers to know their work environment and the factors that interfere with their health.
1 Nurse. University Potiguar UNP-Campus Mossoro. (RN), Brasil.

2 Nurse. Master student of the Graduate Program in Nursing, Federal University of Rio Grande do Norte/UFRN. Natal(RN), Brazil.

3 Nurse. Ph.D. in Health Science. Professor of the Graduate Program in Nursing/ School of Nursing Technician, Federal University of Rio Grande does Norte/UFRN. Natal(RN), Brazil.

4 Nurse. Ph.D. in Nursing. Professor of the Nursing Department, Federal University of Rio Grande do Norte/ UFRN. Natal(RN), Brazil.

Contact information:

Yanna Gomes de Sousa.

” yanna_gomes@yahoo.com.br

\section{Keywords}

Nursing; Occupational Health; Occupational Health Nursing; Working

Conditions. 


\section{Introduction}

The changes that occurred in recent decades in the labor market have affected the health of individuals and the collective of workers. Work intensification is a characteristic of the current phase of capitalism The insecurity generated by the fear of unemployment makes people undergo insecure schemes and employment contracts, receiving low wages and risking their lives and health in unhealthy environments, of high risk. [1]

In the workplace, working conditions are essential to the health of workers. The organization of work reduces the chances of avoiding risks, mitigating them or eliminating them while performing their duties.

Occupational Risk is any possibility that some element or existing circumstances in a given process or work environment can cause damage to health, whether through accident, disease or the suffering of workers. [2]

Health problems related to work are classified into two groups: the first group include those who translate into an abrupt disruption of the balance between the conditions and the working environment and workers' health, such as occupational accidents and occupational poisonings; the second group includes chronic nature of diseases: the typical occupational disease, defined as inherent or peculiar to a particular group of activities. [3]

Often, the understanding of workers about occupational risks is inadequate and the protective measures in the area of Safety and Health at Work - SHW neglect prevention practices in the field of medicine and professional safety, contributing to the onset of occupational accidents.

Accidents at work that cost to the employee, company and society affect economic productivity, and are responsible for a substantial impact on the social protection system.

In Brazil, 5.2 million of benefits were granted in 2013 , of which $86.7 \%$ were social security, $6.5 \%$ accident and $6.8 \%$ were clinical. Compared to 2012, the amount of benefits paid increased 5.0\%. Despite all supervision by the Ministry of Labor, Unions and Prosecutors in Brazil between 2011 and 2013, there were 953,820 accidents reported. [4]

Meanwhile, the area of the ceramic factory has a high vulnerability to accidents, with about 25\% of the Brazilian labor. In 2012, there were 308,060 reported accidents at work, $70 \%$ of these cases are male and aged 25 to 29 years old. [5]

The work in the context of a ceramic factory requires the development of theoretical and scientific knowledge about the protective measures in medicine and safety, skills and diverse complexity technical expertise and other skills such as communication, organization, critical observation, among others.

There is a growing interest of researchers by working conditions these professionals are exposed, their suffering-pleasure relationship and knowledge of the risks inherent in their profession, especially in the ceramic factory. However, there are few studies on this relationship in other areas of nursing practice.

Among these areas, the Ceramics Industries are establishments that are aimed at the production of artifacts from clay and alloying elements such as gravel, making plastic and easy mix shape when wet. After being subjected to the drying process to remove moisture from the material, the molded part is exposed to temperatures of $1,000^{\circ} \mathrm{C}$, which provides rigidity and resistance equipment with the merger of certain components of the mass. In some situations, it is also made impregnation varnish on the outer surface of the part. All these activities require varied health risk and worker safety. [6]

The Risk Level is to measure the risk of each activity. This measure is made considering the field of activity of the company. In the ceramic factory, the nursing work is not developed directly in these institutions since the adopted legislation only obliges the ceramic companies to hire nurses when their quantitative employees exceed 3,501 workers. [7] 
Contact between the nursing professional and ceramic factory worker happens routinely in the Family Health Strategy - FHS as individual in the community where he is inserted in an area linked to the health team, and to perform first aid in case of accidents work. [8]

The resolution and/or referral of these problems are through the resoluteness of actions undertaken by the multidisciplinary team of the FHS and Occupational Health Surveillance, present in the Municipal Health Department in Brazil. Primary Health Care - PHC has the lead role of care and health care network organization, so the expansion of health surveillance, including Environmental Health and Occupational Health should be implemented in every day of FHS health professionals. [9]

The Surveillance Occupational Health is a continuous and systematically activity to detect, understand, research and analyze the determinants and conditions of health problems related to the processes and work environments in their technological, social, organizational and epidemiological aspects, to plan, implement and evaluate interventions on these aspects and to eliminate them or control them. [10]

All this reflective process created the following question: which is the employee awareness of occupational risks to which they are exposed? Given these considerations, this study aimed to identify the workers' awareness of a ceramic factory on occupational risks to which they are exposed.

The development of this research is a necessity because these risks need to be unraveled to understand the working environment, the different types of risks, the factors and the measures that must be taken to avoid environmental aggression on the individual.

This study was very important for creating effective preventive interventions in minimizing harm to workers' health because the first step to avoid injury is to know the factors that can cause them. Also, that approach could bring a reflection for workers, managers and the health team to review security issues to eliminate or minimize the risks while preserving the employee's integrity.

\section{Method}

Exploratory and descriptive study of a qualitative approach conducted with workers of a ceramics factory located in Rio Grande do North- Brazil. The company is highlighted by the ceramic production factory in the state, polarizing Rio Grande do Norte, Pernambuco, and Paraíba.

This company manufactures bricks and tiles. It has shift working of eight hours a day, from 7 a.m. to $5 \mathrm{~m}$. with a break for meals from 12 p.m. to 1 p.m. and a weekly rest on Sundays. It has been operating for 11 years and currently employs 45 workers, 43 men, and two women, working in the following sectors: office, oven, civil maintenance, production, and transportation.

The study workers who met the following inclusion criteria participated in the study: employment bond working on the books, performance material production functions (ceramist, controller, brick holder, brick usher, motorcycle driver, car porter, woodman, burner, oven filler, oven dryer and mechanic), these criteria were chosen to understand that these functions are the ones that offer increased risk to workers.

The data collection process was from October to November 2015, through the focus group methodology to obtain qualitative information in depth. Questions were used for the awareness of occupational risks and occupational exposure of workers.

The focus group was held collectively, in a meeting place within the company, in a combined day with the research participants and those responsible for the company. It had an average duration of two hours and was recorded with an audio recorder (portable recorder) to record the speech and then transcribed literally to maximize reliability. 
The interviews' information was stored on a laptop and pen drive of the authors of the research, as well as on a CD that remains stored in personal teacher's closet and researcher responsible for five years at the University Potiguar- UNP deleted and destroyed after this time.

Data were evaluated using the collective subject discourse analysis. The CSD is the organization and tabulation of qualitative data of verbal nature, obtained by testimonials taking the central ideas, the anchors, and their corresponding key expressions.

The study was developed in line with current ethical regulations (Res. 466/2012-CNS), with prior approval of the research project by the Ethics Committee of the University Potiguar UNP- under CAAE number 47474215.1.0000.5296 and opinion number 1.212.613.

\section{Results}

The study included 12 workers of different functions: most of them were porters, drivers, mechanics, bricklayer, and oven man, all male. The age ranged between 18 and 65 years old, with most of the respondents between 20 and 30 years old. Regarding the level of education, nine workers had completed elementary school, and three workers had high school diplomas.

The workday is usually 8 hours divided between the morning, afternoon and evening shift. Most of the professionally developed activities in the ceramics factory for five years. The focus group duration averaged was 2 hours.

After the analysis of focus group data, four categories were organized seeking a common point between the discourses: employee awareness of occupational risks; types of risk in the activities developed by the workers; form of prevention used by workers against occupational hazards; and the importance of educational activities on occupational risks and ways of protecting these risks.

\section{Discussion}

\section{Category 1. Workers' awareness on occupational risks}

When the workers were asked about the understanding of occupational risks, they showed some knowledge, according to the Collective Subject Discourse (CSD) described:

Risks at work are what can cause accidents, so we must be alert to avoid them, and these accidents are both even in the factory or on the way to work.

CSD 1.

In the workers' speech, it is noticed a clarification about what risk means and what impact may have on health and life. When clarifying that they must "be alert to avoid accidents," we noted that they understand the importance of recognizing these risks to have a better quality of life and work activities.

The concept of risk varies according to the perception of each because humans have different perceptions about the risks to which they are exposed. Thus, the experiencing risk is the variation of individual differences, also admitting to that knowledge about the risks has influences of individual experiences and collective construction of risk, not only the result of the exposure. [11]

In recent years, the ceramic factory embraced mass production, backed by industry equipment, and new technologies are being gradually introduced in ceramics. This automation accelerates production and minimize the exposure of workers to the risks and harmful agents to health and safety. However, if these innovations improve some aspects, on the other hand, it exposes workers to new risks related to accelerating rhythms, like stress and repetitive strain injuries. [12]

The activity in the ceramic is undoubtedly of great importance from the point of view of employability, but it must be recognized that this process also has caused serious social problems evidenced in the 
harsh reality imposed on many workers who are subjected to poor working conditions and low wages, comprehensive daily journey that is intensifying every day in Brazil. [13]

According to the International Labor Organization, the detection of hazards and risk assessment must be considered to identify how they could affect workers and the company to develop and implement appropriate prevention and protection measures. [14]

It is noteworthy that control risks are an important way to seek to protect people from threats to their lives. The recognition by employers of the risks to which workers are exposed, through the legitimation of representations of workers is a key factor in the health of workers. It is not just to pay workers by the experienced risk, with payment for additional health risks and danger, installing protective equipment, diagnosing links between work and health, obtaining social security benefits. [15]

\section{Category 2. Types of risks in the activities undertaken by workers}

As for the performance of labor activities from the perception of the existence of risks, workers highlighted those that most affect them as shown in the following CSD:

Falling off of a truck, brick in the head, repeated movement, the wood that has to be careful not to hit us, hidden bugs in the bricks, shock, darkness, traveling at dawn and accidents on the road and the heat, the dust, the noise, the smoke can harm all who are working.

CSD 2.

Participants described the risks from their experiences within the limits of everyday practice developed to each function as well as the risks in ceramics in general, which can trigger health problems in the health of all workers independent of the function meets.
Thus, the CSD represented that the knowledge on the subject is based on their practical awareness and the concomitant experience.

Thus, the CSD represented that knowledge on the subject is based on their practical knowledge and the concomitant experience.

Risk factors vary in severity and function. However, for all of them, the professional should adopt security measures to prevent accidents and develop a safe work. [16] It was noted that workers in addition to knowing which define the risks in their function, they can relate them to the damage they can bring to their health, expressing concern about the possible effects that their activities may cause.

Recognizing the importance of identifying risk in the workplace will make them healthier and less harmful to workers' health. The worker as a subject suffering from the inadequacy of this environment and seeing the consequences of risks in his body, need to realize the conditions and what they are submitted and know what bothers them, make them suffer, sick and accident to then interferes with this reality. [17]

\section{Category 3. Form of prevention used by workers against occupational risks}

Regarding the prevention of accidents at work, all workers cited the importance of using the Personal Protective Equipment (PPE) and Collective Protection Equipment - CPE that are provided by the company, according to the speech:

The company gives us the PPE to protect, which are gloves, boots, helmets, thermal apron, ear plugs, masks, goggles and insulate the wires from the shock risk by working with energy and protection on the machines.

CSD3.

PPE is considered every device or product for individual use by the worker, for the protection of susceptible risks to threaten the safety and health at work. The company is required to provide to em- 
ployees, free PPE appropriate to the risk, in perfect conservation and working condition, when the general measures do not provide complete protection against the risks of occupational accidents or professional and occupational diseases when the collective security measures are being implemented and to meet emergency situations. [18]

PPE are intended to neutralize the action of certain accidents that could cause injuries to workers and protect them against possible damage to health caused by the conditions of work. [19] Examples of PPE are: the masks, ear protectors, boots, gloves, helmets, thermal clothing, among many others that suit every existing unhealthy activity.

It is evident that all workers know the importance of using PPE during their work activities. However the non-use by workers was a concerning factor noted in the focus group, according to the following CSD:

Often, we do not use them, even when the company requires it, such as the mask that we know it protects against dust and smoke, but it is not comfortable because it is warm and forces the service.

CSD4.

Despite the report on the importance of the use of PPE during work activities, 8 out of 12 respondents complaint about not being comfortable and they do not use them. Many workers are uncomfortable with the use of equipment and do not fulfill their duties in use. The employee will adhere more to the PPE as comfortable and pleasant it is. Thus, that material must be practical, secure well, easy to maintain and durable. [19]

The PPE is usually the last barrier to prevent injury, defined from the risks identified in the work environment and the possibilities of failure of the protections and pre-established systems.

However, many times, the awareness processes and application of the rules are not always efficient. To work the safety culture with the worker, he must face and accept the risks of his activity. If he is aware of the importance of the use of equipment, he will also have the behavior to follow the rules. [20]

\section{Category 4. Importance of educational activities on occupational risks and ways of protecting these risks}

The following speeches reveal what the professionals think of the importance of carrying out educational activities on occupational risks and ways of prevention interventions to environmental risks:

It is important the company provide information about it, advise on the use of protection, to adjust and try to respect the rules of the mandatory use of PPE, doing good for the health of the people and also making known the risks of diseases related to heat, dust, and smoke.

CSD5.

The actions of interventions through educational activities are important because, through them, they can receive complaints relating to situations of occupational risks and working with the broader concept of work health disease.

All respondents reported that the implementation of educational activities in the workplace was of great importance for professional practice and the prevention of occupational accidents. The statements show interest by professionals with the quality of life in the workplace, and it also shows the professional commitment to prevent risks.

The 12 workers reported that the company is very present when it comes to bringing knowledge about the quality of life in the work environment being of paramount importance as health education and improve the quality of life offering means to improve the quality of products and services, generating greater efficiency and performance at work.

Health education should be seen as an important aspect of prevention, and that the practice should be concerned with the improvement of living conditions and health of populations. 
To achieve an adequate level of health, people need to know how to identify and meet their basic needs. They should be able to adopt changes in behaviors, practices, and attitudes, as well as the necessary means to operationalize these changes. In this sense, health education means to help people to acquire autonomy to identify and use the ways and means to preserve and enhance their life. [21]

The effective worker participation in the adoption of measures to prevent harm to their integrity reduces costs of prevention, improves working conditions, product quality, and process productivity. The educational practice should be held in accessible language emphasizing the activities that the company develops and their inherent risks. Thus, the worker shall be able to collaborate in the promotion of working conditions and provides the company grants to improve the tactical, strategic and operational planning. [21]

The awareness by workers and managers of the industries regarding health and safety in the production process can come to ensure the best quality of the work environment. As a most surprising result, we can mention the "feeling" of the host by the employee, feeling important for the factory: if the company takes good care of his health, he should also take good care of the company. From there, a network of solidarity is installed, creating conditions for other health actions, adding quality of life to the worker. [21]

\section{Conclusions}

This study allowed us to analyze the knowledge of the ceramic factory workers about occupational risks they are exposed to in daily work.

During the research, it was found to ease the adherence of the company to collaborate providing the structure and allowing workers to participate. The workers were very receptive to the research, so there was no difficulty in achieving the objectives.
The analysis evidenced that workers perceive and identify the risks by their work environment and can relate to such risks with their health implications. However, based on speeches obtained, it can be observed that there is still a lot of resistance to the use of personal protective equipment for workers because they feel it as an uncomfortable equipment.

The worker is who suffer most from the inadequacies of the environment and work process feeling the discomfort, suffering, illness and accidents that can affect their quality of life. Therefore, it is essential he is the principal involved in the elimination process and identification of these risks, for improvement in their health, life, and work.

To encourage the use of PPEs, people responsible for the work safety would influence following employees daily, and this could be done through periodic inspections at work.

Therefore, it is important that the company and the employee are united in the creation of prevention and elimination of risks by continuing educational activities that enlighten and sensitize the workers to know their work environment and the factors that interfere with their health.

It is understood that security is a responsibility of all who are linked to the company so that everyone do their part and practice actions about health and safety at work.

\section{References}

1. Elias MA, Navarro VL. The relation between work, healthand living conditions: Negativity and positivity in nursing work at a teaching hospital. Rev. Latino-Am. Enfermagem. 14(4):517-525. 2006

2. Silva EJ da, Lima MG, Marziale MHP. The concept of risk and its symbol icef fects in accidents with sharp instruments. Rev. bras. enferm. 65(5): 809-814. 2012

3. Mendes R. Patologia do trabalho. Rio de Janeiro (RJ): Atheneu; 1995

4. Ministério da Previdência Social. Anuário Estatístico da Previdência Social. Brasília : MPS/DATAPREV, 2013.

5. Tribunal Regional do Trabalho. Número de acidentes de trabalho ainda é alarmante no Brasil e no Estado. Rio Grande do Sul, 2014. 
6. Ministério da Saúde. Doenças relacionadas ao trabalho Manual de Procedimentos para os Serviços de Saúde. Série A. Normas e Manuais Técnicos; n. 114 Brasília/DF - Brasil 2001.

7. Ministério do Trabalho e Emprego. NR 4- serviços especializados em engenharia de segurança e em medicina do trabalho. Brasília, 1978.

8. Dias EC, Thais LS e., Magda HCA de. Desafios para a construção cotidiana da Vigilância em Saúde Ambiental e em Saúde do Trabalhador na Atenção Primária à Saúde. Cad. Saúde Colet.20(1):15-24. 2012.

9. Dias EC, Silva TL e. Contribuições da Atenção Primária em Saúde para a implementação da Política Nacional de Saúde e Segurança no Trabalho (PNSST). Rev. bras. saúde ocup.38(127): 31-43. 2013

10. Ministério da Saúde.Portaria n 3.120, de $1^{\circ}$ de julho de 1998. Departamento Nacional de Auditoria do SUS. Coordenação de Sistema de Informação. Sistema Único de Saúde. Legislação Federal.

11. Soares JFS. Saúde do trabalhador e risco no ambiente de trabalho: conhecimento dos trabalhadores portuários avulsos (TPA's) do porto do Rio Grande - RS /Rio Grande: Dissertação [Mestrado em Enfermagem] - FURG; 2006.

12. Gomes MHP. Manual de Prevenção de Acidentes e Doenças do Trabalho nas Olarias e Cerâmicas Vermelhas de Piracicaba e Região. Piracicaba - SP: Olarias e Cerâmicas Vermelhas de Piracicaba e Região, 2010.

13. Rocha FRF. Segurança do trabalhador em uma indústria de cerâmica vermelha no município de itajá/RN. UFERSA. AngicosRN, 2013.

14. Organização internacional do trabalho. Sistema de Gestão da Segurança e Saúde no Trabalho: Um Instrumento para uma Melhoria Contínua. 2011

15. SOARES, J et al. Hazards to worker's health: a literature review. Online Brazilian Journal of Nursing. 5(3). 2006. Acesso: http:// www.objnursing.uff.br/index.php/nursing/article/view/510/118

16. Dias TMA. Percepção dos trabalhadores de soldagem em relação à exposição aos riscos de acidentes no local de trabalho. Revista Enfermagem Contemporânea. 4(1): 49-55. 2015.

17. Santo AFE, Paula JA, Pereira OAV. Percepção de trabalhadores de uma indústria têxtil sobre os riscos de seu ambiente de trabalho. Revista Enfermagem Integrada. 2(1): 188-199. 2009

18. Ministério do Trabalho e Emprego. NR 6 - equipamento de proteção individual - EPI. Brasília, 1978
19. Silva MP. A importância do uso de epi na prevenção de acidentes de trabalho na indústria madeireira. FACIDER-Revista Científica. 3(3): 1-14. 2013.

20. Garbaccio JL; Oliveira AC de. Adesão e conhecimento sobre o uso de equipamentos de proteção individual entre manicures e pedicures. Rev. Bras. Enferm.68(1): 52-59. 2015

21. Oliveira HM, Gonçalves MJF. Educação em saúde: uma experiência transformadora. Revista Brasileira de Enfermagem. 57(6): 761-763. 2004

22. Luz FR da, Loro MM, Zeitoune RCG, Kolankiewicz ACB, Rosanelli CSP. Occupational risks of a shoe industry from the workers' perspective. Rev Bras Enferm. 66(1): 67-73. 2013
Publish in International Archives of Medicine

International Archives of Medicine is an open access journal publishing articles encompassing all aspects of medical science and clinical practice. IAM is considered a megajournal with independent sections on all areas of medicine. IAM is a really international journal with authors and board members from all around the world. The journal is widely indexed and classified Q1 in category Medicine. 